\title{
Fermentation profile and nutritional value of sunflower silage with Urochloa brizantha cultivars in the off-season
}

\author{
Perfil fermentativo e valor nutritivo da silagem de girassol com cultivares de \\ "Urochloa brizantha" na safrinha
}

\section{CRUVINEL, Welma Santos ${ }^{1}$; COSTA, Kátia Aparecida de Pinho ${ }^{1 *}$; TEIXEIRA, Daniel Augusto Alves ${ }^{1}$; DA SILVA, Jessika Torres ${ }^{1}$; EPIFANIO, Patrícia Soares ${ }^{1}$; COSTA, Pedro Henrique Campos Pinho ${ }^{2}$; FERNANDES Patrick Bezerra ${ }^{3}$}

\author{
${ }^{1}$ Instituto Federal Goiano, Programas de Pós-Graduação em Zootecnia e Ciências - Agronomia, Rio \\ Verde, Goiás, Brasil. \\ ${ }^{2}$ Universidade Federal de Goiás, Goiânia, Goiás, Brasil. \\ ${ }^{3}$ Universidade Federal de Mato Grosso do Sul, Campo Grande, Mato Grosso do Sul, Brasil. \\ *Endereço para correspondência: katia.costa@ifgoiano.edu.br
}

\section{SUMMARY}

Sunflower as silage is an alternative to be used in the off-season, when water shortage makes traditional crops unfeasible. However, exclusive sunflower silages have levels above $70 \mathrm{~g} / \mathrm{kg} \mathrm{DM}$ ether extract, which may impair ruminal fermentation. Thus, ensiling sunflower with tropical forages can bring benefits to the quality of the silage. This study evaluated the fermentation profile and nutritional value of sunflower silage with cultivars of Urochloa brizantha in the off-season. This was a completely randomized experimental design with four replications. The treatments were composed of the sunflower silage with and without addition of cultivars of Urochloa brizantha in the ensiling process: sunflower silage; sunflower silage $+30 \%$ Marandu palisadegrass; sunflower silage $+30 \%$ Xaraes palisadegrass; sunflower silage $+30 \%$ Piata palisadegrass and sunflower silage $+30 \%$ Paiaguas palisadegrass, totaling 20 experimental silos. The addition of the cultivars of Urochloa brizantha to sunflower silage contributed to improve the fermentation profile and nutritional value of the silages. Silages with $30 \%$ Piata and Paiaguas palisadegrass showed higher levels of $\mathrm{CP}$ and lower levels of ADF and lignin, and these cultivars are the most recommended for ensiling with sunflower.
Keywords: chemical composition, in vitro dry matter digestibility, ensilage, Helianthus annuus $L$.

\section{RESUMO}

O girassol sob forma de silagem é uma alternativa para ser utilizado no período de safrinha, em que a deficiência hídrica torna as culturas tradicionais inviáveis. No entanto, a silagens exclusiva de girassol apresentam níveis acima de $70 \mathrm{~g} / \mathrm{kg}$ MS de extrato etéreo, o que pode comprometer a fermentação ruminal. Sendo assim, a ensilagem do girassol com forrageiras tropicais pode trazer benefícios para a qualidade da silagem. Sendo assim, objetivouse avaliar o perfil fermentativo e o valor nutritivo da silagem de girassol com cultivares de Urochloa brizantha na safrinha. O delineamento experimental utilizado foi $o$ inteiramente casualizado, com quatro repetições. Os tratamentos foram constituídos da silagem de girassol com e sem adição de cultivares de Urochloa brizantha na ensilagem: silagem de girassol; silagem de girassol $+30 \%$ do capim-marandu; silagem de girassol $+30 \%$ do capim-xaraés; silagem de girassol $+30 \%$ do capim-piatã e silagem de girassol $+30 \%$ do capim-paiaguás, totalizando 20 silos experimentais. Os resultados demonstraram que as silagens com adição dos cultivares de Urochloa brizantha, contribuíram para melhorar 
o perfil fermentativo e valor nutricional das silagens. Silagens com $30 \%$ dos capins piatã e paiaguás apresentaram maiores teores de $\mathrm{PB}$ e menores teores de FDA e lignina, sendo mais recomendadas para ensilagem com girassol.

Palavras-chave: composição bromatológica, digestibilidade in vitro da MS, ensilagem, Helianthus annuus $L$.

\section{INTRODUCTION}

Sunflower (Helianthus annuus L.) is one of the oilseeds with the highest growth rates worldwide due to the production of plant oil with excellent physical, chemical and nutritional characteristics (SOUZA et al., 2005).

The high efficiency in using the water available in the soil for its development, ability to produce large amount of dry mass under water stress and the tolerance to the wide temperature range, without significant reduction in production, are characteristics that have enabled the production of sunflower silage in the off-season or in locations where water deficiency makes it unfeasible for crops traditionally used for this purpose, such as corn (TOMICH et al., 2003).

Another characteristic of sunflower is the high concentration of ether extract $(147 \mathrm{~g} / \mathrm{kg})$ in silage (TOMICH et al., 2004), therefore, these silages can lead to reduction in ruminal fermentation, fiber digestibility and passage rate. In addition, the sunflower also presents differences in the composition of the cell wall, giving it particular characteristics (LEITE et al., 2006). However, the dry matter content of the forage, below $250 \mathrm{~g} / \mathrm{kg}$ may compromise the silage fermentation (TOMICH et al., 2004; POSSENTI et al., 2005; BITENCOURT JUNIOR et al., 2008). According to McDonald (1981), silages made with low dry matter content trigger drainage losses and promote the development of bacteria of the genus Clostridium due to the excessive moisture of the forage.

Therefore, sunflower silages added with tropical forages can bring great benefits to the quality including decrease in ether extract content, acid detergent fiber, lignin, besides the production of silage in the off-season, with sufficient quality and quantity for nutritional maintenance of ruminants. Thus, the present study aimed to evaluate the fermentation profile and nutritional value of sunflower silage with cultivars of Urochloa brizantha in the off-season.

\section{MATERIAL AND METHODS}

The experiment was conducted in the field $\left(17^{\circ} 48^{\prime} \mathrm{S} ; 50^{\circ} 55^{\prime} \mathrm{W}\right.$; and $748 \mathrm{~m}$ altitude) in the municipality of Rio Verde, state of Goiás, in the off-season, in a Latossolo Vermelho distroférrico. The physical-chemical characterization of the soil sample from the experimental area at the $0-20 \mathrm{~cm}$ layer was $510 ; 160$; $330 \mathrm{~g} \mathrm{~kg}^{-1}$ clay, silt and sand, respectively; $\mathrm{pH}$ in $\mathrm{CaCl}_{2}: 5.10 ; \mathrm{Ca}$ : 2.88; Mg: 1.27; Al: 0.01; $\mathrm{Al}+\mathrm{H}: 4.00 ; \mathrm{K}$ : 0.39; CEC: 8.54 in $\mathrm{cmol}_{\mathrm{c}} \mathrm{dm}^{-3}$; P: 8.72; $\mathrm{Cu}: 3.4 ; \mathrm{Zn}: 1.5 ; \mathrm{Fe}: 43.0 \mathrm{mg} \mathrm{dm}^{-3}$ and OM: $26.76 \mathrm{~g} \mathrm{dm}^{-3}$.

The experiment was a completely randomized design with four replications. The treatments were composed of the sunflower silage with and without addition of cultivars of Urochloa brizantha in the silage: sunflower silage; sunflower silage + 30\% Marandu palisadegrass; sunflower silage $+30 \%$ Xaraes palisadegrass; sunflower silage $+30 \%$ Piata palisadegrass and sunflower silage + $30 \%$ Paiaguas palisadegrass, totaling 20 experimental silos. The sunflower 
cultivar used was Charrua (triple hybrid, semi-early, with black achenes and high oil content).

For ensilage, we used the material of intercropping sunflower with cultivars of Urochloa brizantha. Grasses were sown in the sunflower interrow $0.25 \mathrm{~m}$ from the row. Each plot consisted of eight rows $3.0 \mathrm{~m}$ in length, $0.50 \mathrm{~m}$ spaced apart. The useful area was obtained by disregarding one row on each side of the plots and $0.5 \mathrm{~m}$ from each end.

The preparation of the area was performed with the desiccation of weeds with glyphosate ( $720 \mathrm{~g}$ e.a./ha) in a volume of $150 \mathrm{~L} / \mathrm{ha}$. Thirty days after desiccation, the area was harrowed for elimination of weeds not controlled by the herbicide, followed by disking, due to intense infestation of guinea grass in the area. One week before the implementation of the test, a second harrowing and disking was performed using an automatic seeder. Furrows for sowing Urochloa brizantha cultivars, in the interrows of sunflower, were manually opened using hoes.

The sowing was carried out on February $18^{\text {th }}$, using $80 \mathrm{~kg} / \mathrm{ha} \mathrm{P}_{2} \mathrm{O}_{5}, 20 \mathrm{~kg} / \mathrm{ha}$ FTE BR 12 with $1.5 \mathrm{~kg}$ boron, as single superphosphate, fritas and boric acid, respectively. For sunflower planting, six seeds were sown per meter and for forage species, $5 \mathrm{~kg}$ viable pure seeds per hectare. Seeds of the Paiaguas palisadegrass were supplied by Embrapa Beef Cattle, through the material transfer agreement signed with the Instituto Federal de Goiano, Rio Verde Campus (20.500,13/0013-1).

At 20 and 40 days after emergence of seedlings (DAE), $50 \mathrm{~kg} /$ ha nitrogen, 40 $\mathrm{kg} / \mathrm{ha} \mathrm{K}_{2} \mathrm{O}$ and $1.5 \mathrm{~kg} / \mathrm{ha}$ boron, as urea, potassium chloride and boric acid, respectively, were applied through broadcasting.

For the post-emergence control of weeds, manual weeding was performed every week up to 45 DAE. Pest control was carried out manually at 70 DAE, with the application of the insecticide teflubenzuron, at the dose of $1 \mathrm{~L} / \mathrm{ha}$, for the control of bordered patch caterpillar (Chlosyne lacinia saundersii) and application of the insecticide epinosade to control the soybean looper caterpillar (Pseudoplusia includens) at the dose of $1 \mathrm{~L} /$ ha with spray volume equivalent to 300L/ha.

For silage, the sunflower and cultivars of Urochloa brizantha were harvested separately in the 105-day cycle, at the pasty phenological stage of achenes, at $20 \mathrm{~cm}$ from the ground, using a backpack mower. Subsequently, the forages were ground separately, in a stationary forage machine (Nogueira EM-9F3B), into particles of 10 to $30 \mathrm{~mm}$. The material was then homogenized with $30 \%$ Marandu, Xaraes, Piata and Paiaguas palisadegrass, on a natural matter basis, and stored in experimental PVC silos measuring $10 \mathrm{~cm}$ in diameter and $40 \mathrm{~cm}$ in length.

The mean density of the silos was 1.12 $\mathrm{kg} \mathrm{dm}^{3}$. Silos were closed with PVC caps and sealed with adhesive tape to prevent the entry of air. Soon after, they were stored at room temperature and protected from rain and sunlight.

After 50 days of fermentation, silos were opened, discarding the silage of the top and bottom of each. The central portion of the silo was homogenized and placed on plastic trays. Part of the fresh silage after opening the silos was separated to be analyzed the $\mathrm{pH}$ values by the method described by Silva \& Queiroz (2002) and a subsample was used to the quantification of the buffering capacity, according to methodology described by Playne \& McDonald (1966).

After this procedure, a silage sample was taken and divided into two parts. The first was packed in plastic bags and frozen. The other subsample of $25 \mathrm{~g}$ 
silage was added with $200 \mathrm{~mL} 0.2 \mathrm{~N}$ $\mathrm{H}_{2} \mathrm{SO}_{4}$ solution and remained in the refrigerator for 48 hours, then filtered through a Whatman ${ }^{\circledR} 54$ filter paper. This filtrate remained in the refrigerator until the determination of $\mathrm{N}-\mathrm{NH}_{3}$ (BOLSEN et al., 1992).

To determine the organic acids, $25 \mathrm{~g}$ fresh silage were weighed and mixed with $225 \mathrm{~mL}$ distilled water in the blender for one minute, later, this material was filtered through filter paper. Then, $2 \mathrm{~mL}$ of this filtrate was taken and $1 \mathrm{~mL} 20 \%$ metaphosphoric acid solution was added and frozen for the analysis of lactic, acetic, propionic and butyric acids in high performance liquid chromatograph (HPLC), Shimadzu, SPD-10A VP, coupled to a ultraviolet (UV) detector, using a wavelength of 210nm (KUNG JUNIOR \& RANJIT, 2001).

The other part of the silage, with approximately $1 \mathrm{~kg}$, was weighed and taken to a forced ventilation oven at $55^{\circ} \mathrm{C}$ for 72 hours for the determination of the pre-dried matter. Next, samples were ground in a Willey mill with a $1 \mathrm{~mm}$ mesh sieve for analysis.

Chemical analyses were conducted for determination of dry matter (DM), crude protein $(\mathrm{CP})$, neutral detergent fiber (NDF), acid detergent fiber (ADF), mineral matter (MM) and ether extract (EE) by the method of AOAC (1990), lignin in sulfuric acid (VAN SOEST et al., 1994) and the total digestible nutrients (TDN) was obtained using the equation proposed by Chandler (1990).

The technique described by Tilley \& Terry (1963), adapted to the artificial rumen developed by $\mathrm{ANKON}^{\circledR}$, was used to determine the in vitro dry matter digestibility (IVDMD), using the instrument Daisy incubator by Ankom Technology (in vitro true digestibilityIVTD).

Before ensiling, a chemical analysis of the forage was performed according to the methodologies described above (Table 1).

Table 1. Chemical composition of sunflower and cultivars of Urochloa brizantha before ensiling

\begin{tabular}{lccccc}
\hline Composition & Sunflower & $\begin{array}{c}\text { Marandu } \\
\text { palisadegrass }\end{array}$ & $\begin{array}{c}\text { Xaraes } \\
\text { palisadegrass }\end{array}$ & $\begin{array}{c}\text { Piata } \\
\text { palisadegrass }\end{array}$ & $\begin{array}{c}\text { Paiaguas } \\
\text { palisadegrass }\end{array}$ \\
\hline DM (g/kg MS) & 245.6 & 326.0 & 314.0 & 325.1 & 308.2 \\
MM (g/kg MS) & 93.2 & 63.5 & 68.3 & 55.4 & 57.8 \\
CP (g/kg DM) & 129.2 & 131.2 & 138.7 & 140.2 & 145.6 \\
EE (g/kg DM) & 135.7 & 30.8 & 29.7 & 31.6 & 24.8 \\
NFC (g/kg DM) & 75.9 & 119.2 & 94.9 & 125.8 & 136.6 \\
NDF (g/kg DM) & 566.0 & 655.3 & 668.4 & 647.0 & 635.2 \\
ADF (g/kg DM) & 494.5 & 387.0 & 390.6 & 355.0 & 348.5 \\
Lignin (g/kg DM) & 80.5 & 49.0 & 37.5 & 47.3 & 31.9 \\
TDN (g/kg DM) & 703.5 & 576.8 & 593.0 & 587.0 & 571.2 \\
IVDMD (g/kg DM) & 516.5 & 625.0 & 638.3 & 642.1 & 639.5 \\
BC (eq.mg HCL/100g & 165.0 & 282.0 & 259.0 & 264.5 & 249.0 \\
DM) & & 28.0 & & \\
\hline
\end{tabular}

$\mathrm{DM}=$ dry matter; $\mathrm{MM}$ : mineral matter; $\mathrm{CP}=$ crude protein; $\mathrm{EE}=$ ether extract; $\mathrm{NFC}=$ non-fiber carbohydrate; $\mathrm{NDF}=$ neutral detergent fiber; $\mathrm{ADF}=$ acid detergent fiber; $\mathrm{TDN}=$ total digestible nutrients; IVDMD = in vitro dry matter digestibility; $\mathrm{BC}=$ buffering capacity. 
The results were tested by analysis of variance by the statistical software SISVAR 4.6 (FERREIRA, 2011) and the means were compared by Tukey's test at $5 \%$ probability level of type I error.

\section{RESULTS AND DISCUSSION}

Values of $\mathrm{DM}, \mathrm{pH}$, titratable acidity, butyric acid (Table 2), CP, EE, TDN (Table 4), NDF, ADF, lignin and IVDMD (Table 5) of the silages were influenced $(\mathrm{P}<0.05)$ by addition of the cultivars of Urochloa brizantha. However, for the values of buffering capacity, $\mathrm{N}-\mathrm{NH}_{3} / \mathrm{NT}$, lactic acid, acetic acid, propionic acid and NDF contents, there was no significant difference $(\mathrm{P}>0.05)$ between the silages.

The sunflower silage presented lower DM content, differing from the silages with cultivars of Urochloa brizantha (Table 2). The addition of grasses in sunflower silage contributed to increase the DM content of the material, because the forage species present higher DM contents, since they were harvested in the 105 day growth cycle. It is worth noting that although forages were harvested at the reproductive stage, they had average dry matter contents of $320 \mathrm{~g} / \mathrm{kg}$ at the time of silage cutting. This is due to the shading effect of the intercropping system. Oliveira et al. (2010) reported that it is common to find lower DM content for sunflower silages, since the plant tissue structure has large amounts of moisture.

Moisture content above $35 \%$ favor losses of DM, thus increasing the content of ammonia nitrogen and reducing the soluble carbohydrate (JOBIM et al. (2003). In turn, Muck \& Shinners (2001) reported that DM content less than $30 \%$ may increase the losses in the form of effluent and increase the probability of clostridium fermentation, resulting in food of low acceptability.

Table 2. Fermentation characteristics of sunflower silages with cultivars of Urochloa brizantha

\begin{tabular}{lccccc}
\hline Silages & $\begin{array}{c}\mathrm{DM} \\
(\mathrm{g} / \mathrm{kg})\end{array}$ & $\mathrm{pH}$ & $\mathrm{TA}$ & $\begin{array}{c}\mathrm{BC}(\mathrm{eq} . \mathrm{mg} \\
\mathrm{HCL} / 100 \mathrm{~g} \\
\mathrm{DM})\end{array}$ & $\begin{array}{c}\mathrm{N}-\mathrm{NH}_{3}(\mathrm{~g} / \mathrm{kg} \\
\text { total N) }\end{array}$ \\
\hline Sunflower & $254.4^{\mathrm{b}}$ & $5.25^{\mathrm{a}}$ & $5.92^{\mathrm{b}}$ & 185.3 & 26.6 \\
Sunflower + 30\% Marandu palisadegrass & $314.9^{\mathrm{a}}$ & $4.90^{\mathrm{b}}$ & $12.0^{\mathrm{a}}$ & 164.2 & 22.4 \\
Sunflower + 30\% Xaraes palisadegrass & $318.2^{\mathrm{a}}$ & $4.83^{\mathrm{b}}$ & $13.0^{\mathrm{a}}$ & 172.5 & 22.1 \\
Sunflower + 30\% Piata palisadegrass & $324.5^{\mathrm{a}}$ & $4.75^{\mathrm{b}}$ & $14.0^{\mathrm{a}}$ & 161.0 & 25.1 \\
Sunflower + 30\% Paiaguas palisadegrass & $303.1^{\mathrm{a}}$ & $4.94^{\mathrm{b}}$ & $11.7^{\mathrm{a}}$ & 156.7 & 24.7 \\
CV \% & 6.79 & 6.00 & 12.82 & 13.1 & 2.59 \\
\hline
\end{tabular}

Means followed by different letters are significantly different by Tukey's test at $5 \%$ probability.

DM: dry matter; TA: titratable acidity; $\mathrm{BC}$ : buffering capacity; $\mathrm{N}-\mathrm{NH}_{3}$ : ammonia nitrogen.

The $\mathrm{pH}$ value of a food can be used as one of the main parameters in determining the colonization and activity of the microorganisms, besides being used as a standard of silage quality (AMARAL et al., 2007). The highest $\mathrm{pH}$ value was found in the sunflower silage, which was significantly different $(\mathrm{P}<0.05)$ from the silages with addition of the cultivars of Urochloa brizantha (Table 2). 
It is important to note that even in the silages with the cultivars of Urochloa brizantha, the $\mathrm{pH}$ values did not reach the levels considered adequate, which according to Tomich et al. (2003), is between 3.8 and 4.2 , due to the higher proportion of sunflower $(70 \%)$ in the silage, which at the time of cutting had low dry matter content (Table 1).

By evaluating the titratable acidity, it can be observed in Table 2 that the lowest value was obtained in sunflower silage, perhaps because the silage had the highest $\mathrm{pH}$ value. The titratable acidity is inversely proportional to the $\mathrm{pH}$ values, the higher the $\mathrm{pH}$ value, the lower the titratable acidity. The titratable acidity may aid in the general aspect of the fermentative quality of silage, which influences the taste, odor, color and stability (SILVA \& QUEIROZ, 2002).

Although sunflower silage had a higher $\mathrm{pH}$ value and lower DM content, values of $\mathrm{N}-\mathrm{NH}_{3}$ and buffering capacity were similar between silages, which had a mean content of $\mathrm{N}^{-\mathrm{NH}_{3}}$ of $241 \mathrm{~g} / \mathrm{kg}$ and a buffering capacity of 167.9 (eq.mg $\mathrm{HCL} / 100 \mathrm{~g} \mathrm{DM})$. These results indicate that the studied silages presented adequate fermentations, where the fermentation process did not result in excessive breakdown of protein into ammonia. Van Soest (1994) reports that $\mathrm{N}-\mathrm{NH}_{3}$ is the product of Clostridium fermentations and should not exceed $110-120 \mathrm{~g} / \mathrm{kg}$ total nitrogen in wellpreserved silages.

The results in Table 3 show that the concentration of lactic, acetic and propionic acids were not affected $(\mathrm{P}<0.05)$ by addition of cultivars of Urochloa brizantha, presenting similar results. However, for butyric acid, there was a higher concentration in sunflower silage. This result may be due to the lower content of dry matter, which favors the development of bacteria of the genus Clostridium. McDonald (1981) reported that silages made with excess moisture promotes the appearance of bacteria of the genus Clostridium, where the development of such bacteria produces undesirable secondary fermentations, with the formation of butyric acid, which characterizes low quality silages.

Table 3. Mean values of organic acids of sunflower silages with cultivars of Urochloa brizantha

\begin{tabular}{lcccc}
\hline Silages & $\begin{array}{c}\text { Lactic } \\
(\mathrm{g} / \mathrm{kg} \mathrm{DM})\end{array}$ & $\begin{array}{c}\text { Acetic } \\
(\mathrm{g} / \mathrm{kg} \mathrm{DM})\end{array}$ & $\begin{array}{c}\text { Propionic } \\
(\mathrm{g} / \mathrm{kg} \mathrm{DM})\end{array}$ & $\begin{array}{c}\text { Butyric } \\
(\mathrm{g} / \mathrm{kg} \mathrm{DM})\end{array}$ \\
\hline Sunflower & 38.4 & 13.7 & 2.20 & $0.90^{\mathrm{b}}$ \\
Sunflower + 30\% Marandu palisadegrass & 35.8 & 12.1 & 1.70 & $0.30^{\mathrm{a}}$ \\
Sunflower + 30\% Xaraes palisadegrass & 39.7 & 12.0 & 1.80 & $0.20^{\mathrm{a}}$ \\
Sunflower + 30\% Piata palisadegrass & 36.3 & 12.3 & 1.60 & $0.20^{\mathrm{a}}$ \\
Sunflower + 30\% Paiaguas palisadegrass & 37.9 & 11.9 & 1.70 & $0.30^{\mathrm{a}}$ \\
CV \% & 16.53 & 15.70 & 19.25 & 21.58 \\
\hline
\end{tabular}

Means followed by different letters are significantly different by Tukey's test at 5\% probability.

The CP content of the sunflower silage was similar to the silages added with 30\% Marandu palisadegrass and Xaraes palisadegrass (Table 4). Nevertheless, the silages with the addition of $30 \%$ Piata palisadegrass and Paiaguas palisadegrass presented the highest contents of $\mathrm{CP}$. These results may be 
correlated with the morphology of these grasses, which present thin stems and, therefore, produce better forage due to the higher leaf: stem ratio (CHIARI et al., 2008; COSTA et al., 2016).

Similar results were obtained by Costa et al. (2011), who evaluated the silages of Urochloa brizantha cultivars with millet meal and found that the silage of the Piata palisadegrass presented higher $\mathrm{CP}$ content when compared to the Marandu palisadegrass and Xaraes palisadegrass silages, due to the higher leaf: stem ratio.

It is important to emphasize that all the silages evaluated had CP content above
$70 \mathrm{~g} / \mathrm{kg}$ DM, which is the critical level for a satisfactory development of ruminal cellulolytic bacteria (VAN SOEST, 1994). These results demonstrate that sunflower silages with cultivars of Urochloa brizantha can be an interesting alternative, especially the sunflower with the Piata and Paiaguas palisadegrass, which were superior to sunflower silage by $34.56 \%$ and $33.80 \%$, respectively. These two options of mixed silage are advantageous to guarantee the supply of better quality feed in the winter, where the CP content normally decreases due to the low temperatures and lack of rainfall, damaging the development of forages.

Table 4. Mean values of CP EE, TDN and MM of sunflower silages with cultivars of Urochloa brizantha

\begin{tabular}{lcccc}
\hline Silages & $\begin{array}{c}\mathrm{CP} \\
(\mathrm{g} / \mathrm{kg} \mathrm{DM})\end{array}$ & $\begin{array}{c}\mathrm{EE} \\
(\mathrm{g} / \mathrm{kg} \mathrm{DM})\end{array}$ & $\begin{array}{c}\text { TDN } \\
(\mathrm{g} / \mathrm{kg} \mathrm{DM})\end{array}$ & $\begin{array}{c}\text { MM } \\
(\mathrm{g} / \mathrm{kg} \mathrm{DM})\end{array}$ \\
\hline Sunflower & $103.6^{\mathrm{b}}$ & $131.1 \mathrm{a}$ & $695.0^{\mathrm{a}}$ & $104.6^{\mathrm{a}}$ \\
Sunflower + 30\% Marandu palisadegrass & $120.8^{\mathrm{b}}$ & $81.2^{\mathrm{b}}$ & $616.4^{\mathrm{b}}$ & $84.8^{\mathrm{b}}$ \\
Sunflower + 30\% Xaraes palisadegrass & $121.7^{\mathrm{b}}$ & $80.7^{\mathrm{b}}$ & $604.0^{\mathrm{b}}$ & $86.0^{\mathrm{b}}$ \\
Sunflower + 30\% Piata palisadegrass & $139.4^{\mathrm{a}}$ & $71.8^{\mathrm{b}}$ & $638.9^{\mathrm{b}}$ & $89.9^{\mathrm{b}}$ \\
Sunflower + 30\% Paiaguas palisadegrass & $138.6^{\mathrm{a}}$ & $79.6^{\mathrm{b}}$ & $628.9^{\mathrm{b}}$ & $84.7^{\mathrm{b}}$ \\
CV \% & 7.85 & 11.71 & 7.98 & 9.68 \\
\hline
\end{tabular}

Means followed by different letters are significantly different by Tukey's test at $5 \%$ probability.

$\mathrm{CP}=$ crude protein; $\mathrm{EE}=$ ether extract; $\mathrm{TDN}=$ total digestible nutrients; $\mathrm{MM}=$ mineral matter.

In relation to EE content, in Table 4, only the sunflower silage differed from the silages with Urochloa brizantha cultivars, with a higher EE content, reaching $131.1 \mathrm{~g} / \mathrm{kg} \mathrm{DM}$, because it is an oilseed crop with high oil content and excellent physical, chemical and nutritional characteristics (Souza et al., 2005). It has a high polyunsaturated fatty acids $(65.3 \%)$ /saturated $(11.6 \%)$ ratio and the polyunsaturated content is largely composed by linoleic acid (65\%) (MACEDO et al., 2008).

Sunflower silage with the addition of Urochloa brizantha cultivars contributed to reduce EE content values, averaging
$78.3 \mathrm{~g} / \mathrm{kg} \mathrm{DM}$, higher than recommended. Therefore, it is important to emphasize that these silages should not be supplied as single forage in the diet for cattle and indicates the possible need for association with other forage foods.

Evaluating the nutritional value of elephant grass silage with addition of sunflower levels, Rezende et al. (2002) verified that in the silage with a mixture of $50 \%$ of sunflower, the content of $\mathrm{EE}$ were $74.9 \mathrm{~g} / \mathrm{kg}$ DM. These results were similar to those obtained in this study with $70 \%$ sunflower and 30\% Marandu palisadegrass, Xaraes palisadegrass, Piata palisadegrass and Paiaguas palisadegrass. 
With respect to TDN content, sunflower silage presented the highest level, differing from silages with addition of cultivars of Urochloa brizantha (Table 4). This result can be attributed to the high EE content in sunflower, which contributes positively to the supply of energy in the diet. TDN content is important, since energy and protein are often the most limiting factors for ruminants (OLIVEIRA et al., 2010). Therefore, increasing TDN content in silage may promote better forage utilization by ruminants, thus providing higher energy intake and better performance of animals (BORJA et al., 2012).

Analyzing the mineral matter (MM) content, it was verified that the sunflower silage had the highest values (Table 4). Possibly, there may have been higher effluent losses, since sunflower silage had lower DM content
(Table 2), resulting in losses of organic material and increasing the relative participation of MM (ASHBELL, 1995). Importantly, higher values of $\mathrm{pH}$ and butyric acid were also observed in the sunflower silage without additive.

The NDF contents were not influenced $(\mathrm{P}<0.05)$ by the evaluated silages. However, in relation to the contents of ADF (Table 5), the silages with 30\% Piata palisadegrass and Paiaguas palisadegrass showed the lowest levels when compared to the sunflower silage and 30\% Marandu palisadegrass and Xaraes palisadegrass. Probably, this is due to the lower proportion of stems that these forages have (CHIARI et al., 2008; COSTA et al., 2016). These results indicate that these forages are better suited for ensiling with sunflower, because they reduce the fiber fractions of sunflower, mainly lignin, contributing to a better digestibility.

Table 5. Mean values of NDF, ADF, lignin and IVDMD of sunflower silages with cultivars of Urochloa brizantha

\begin{tabular}{lcccc}
\hline Silagens & $\begin{array}{c}\text { NDF } \\
(\mathrm{g} / \mathrm{kg} \mathrm{DM})\end{array}$ & $\begin{array}{c}\text { ADF } \\
(\mathrm{g} / \mathrm{kg} \mathrm{DM})\end{array}$ & $\begin{array}{c}\text { Lignin }(\mathrm{g} / \mathrm{kg} \\
\mathrm{DM})\end{array}$ & $\begin{array}{c}\text { IVDMD } \\
(\mathrm{g} / \mathrm{kg} \mathrm{DM})\end{array}$ \\
\hline Sunflower & 493.6 & $424.6^{\mathrm{a}}$ & $75.6^{\mathrm{a}}$ & $527.5^{\mathrm{b}}$ \\
Sunflower + 30\% Marandu palisadegrass & 561.5 & $387.6^{\mathrm{ab}}$ & $59.5^{\mathrm{b}}$ & $631.8^{\mathrm{a}}$ \\
Sunflower + 30\% Xaraes palisadegrass & 567.3 & $360.1^{\mathrm{ab}}$ & $60.2^{\mathrm{b}}$ & $602.8^{\mathrm{a}}$ \\
Sunflower + 30\% Piata palisadegrass & 533.1 & $341.6^{\mathrm{b}}$ & $49.3^{\mathrm{b}} \mathrm{c}$ & $615.3^{\mathrm{a}}$ \\
Sunflower + 30\% Paiaguas palisadegrass & 538.4 & $335.9^{\mathrm{b}}$ & $43.7^{\mathrm{c}}$ & $637.6^{\mathrm{a}}$ \\
CV \% & 7.68 & 6.85 & 8.34 & 3.31 \\
\hline
\end{tabular}

Means followed by different letters are significantly different by Tukey's test at $5 \%$ probability.

$\mathrm{NDF}=$ neutral detergent fiber; $\mathrm{ADF}=$ acid detergent fiber; IVDMD = in vitro dry matter digestibility.

The addition of Urochloa brizantha cultivars to sunflower silage contributed to reduce lignin content in the silages (Table 5), with a decrease of $41.5 \%$, on the average, when compared to sunflower silage, consequently, making the silages more digestible.

This fact can be explained by the recalcitrant nature of lignin, which is minimized and allows better utilization of the fiber by microorganisms. Low lignin contents are important because lignin is not a carbohydrate but an amorphous phenylpropanoid polymer that has a structural function and is considered to be indigestible and inhibits the digestibility of plants (MARANHÃO et al., 2009). Lignin 
plays a strong negative influence on the degradation rate and effective degradability of the cell wall of forages, besides having silica and cutin (VAN SOEST, 1994).

The lowest IVDMD was found in the sunflower silage, differing from the silages with additives (Table 5), demonstrating that addition of the cultivars of Urochloa brizantha contributed to increase the IVDMD of silages, because these forages presented lower levels of ADF and lignin, when compared to the sunflower (Table 1). The increase in digestibility is probably associated with changes in the chemical composition of the fraction with the decrease in NDF, ADF and hemicellulose content, which would certainly provide readily digestible carbohydrates to rumen microorganisms (FERNANDES et al., 2002).

The results showed that the sunflower silage had higher $\mathrm{pH}$, ether extract and lignin, in contrast, lower dry matter content and IVDMD.

The silages with addition of the cultivars of Urochloa brizantha contributed to improve the fermentation profile and nutritional value of silages. Silages with $30 \%$ Piata palisadegrass and Paiaguas palisadegrass showed higher content of $\mathrm{CP}$ and lower content of ADF and lignin, being more recommended for ensiling with sunflower.

\section{REFERÊNCIAS}

AMARAL, R.C.; BERNADES, T.F.; SIQUEIRA, G.R.; REIS, R.A.

Características fermentativas e químicas de silagens de capim-marandu produzidas com quatro pressões de compactação. Revista Brasileira de Zootecnia, v.36, n.3, p.532-539, 2007.

\author{
ASHBELL, G. Basic principles of \\ preservation of forage, by-products \\ and residues as silage or hay. Bet \\ Dagan: Agricultural Research \\ Organization, The Volcani Center. \\ 1995. $58 \mathrm{p}$.
}

\section{ASSOCIATION OF OFFICIAL ANALYTICAL CHEMISTIS - AOAC. Official Methods of Analysis. 15.ed. Arlington, 1990. 1117p.}

BOLSEN, K.K.; LIN, C.; BRENT, B.E. Effect of silage additives on the microbial succession and fermentation process of alfalfa and corn silages.

Journal of Dairy Science, v.75, n.11, p.3066-3083, 1992.

BORJA, M.S.; OLIVEIRA, R.L.; LIMA, L.S.; BAGALDO, A.R.; CARVALHO, G.G.P.; RIBEIRO, C.V.D.M. Sunflower meal concentrations in Massai grass silage.

Revista Cientifica la Facultad de Medicina Veterinaria y Zootecnia MVZ, v.17, n.2, p.3041-3046, 2012.

BITENCOURT JUNIOR, D.; SIEWERDT, L.; HARTHMANN, O.E.L.; ROLL, V.F.B.; ZANIS, F.M. Parâmetros qualitativo e nutricional da silagem de girassol M742 pós-abertura de silo. Revista Brasileira de

Agrociência, v.14, n.2, p.369-373, 2008.

CHANDLER, P. Energy prediction of feeds by forage testing explorer.

Feedstuffs, v.62, p.12, 1990.

CHIARI, L.; ROCHA, M.; VALLE, C.B.; SALGADO, L.R. Variabilidade genética em acessos e cultivares de quatro espécies de Brachiaria estimada por marcadores RAPD. Campo Grande, MS: Embrapa Gado de Corte, 2008. (Boletim de Pesquisa e Desenvolvimento, 24). 
COSTA, K.A.P.; ASSIS, R.L.; GUIMARÃES, K.C.; SEVERIANO, E.C.; ASSIS NETO, J.M.; CRUNIVEL, W.S.; GARCIA J.F.; SANTOS, N.F. Silage quality of Brachiaria brizantha cultivars ensiled with different levels of millet meal. Arquivo Brasileiro de Medicina Veterinária e Zootecnia, v.63, n.1, p.188-195, 2011.

COSTA, R.R.G.F.; COSTA, K.A.P.; SANTOS, C. B.; SEVERIANO, E.C.; EPIFÂNIO, P.S.; SILVA, J.T.; TEIXEIRA, D.A.A.; SILVA, V.R. Production and nutritional characteristics of pearl millet and Paiaguas palisadegrass under different forage systems and sowing periods in the offseason. African Journal of Agricultural Research, v.11, n.19, p.1712-1723, 2016.

FERNANDES, L.D.O.; REIS, R.A.; RODRIGUES, L.R.D.A.; LEDIC, I.L.; MANZAN, R.J. Quality of

Ammoniated Brachiaria decumbens Hay. Revista Brasileira de Zootecnia, v.31, n.3, p.1325-1332, 2002.

FERREIRA, D.F. Sisvar: a computer statistical analysis system. Ciência e Agrotecnologia, v.35, n.6, p.10391042, 2011.

JOBIM, C.C.; BRANCO, A.B.; SANTOS, G.T. Silagem de grãos úmidos na Alimentação de bovinos leiteiros. In: SIMPÓSIO GOIANO SOBRE MANEJO E NUTRIÇÃO DE BOVINOS DE CORTE E LEITE, 5., Goiânia, GO, 2003. Anais... Goiânia, GO, 2003. p.357-376.

KUNG JUNIOR, L., RANJIT, N.K. The effect of Lactobacillus buchneri and other additives on the fermentation and aerobic stability of barley silage. Journal of Dairy Science, v.84, n.5, p.1149-1155, 2001.
LEITE, L.A.; SILVA, B.O.; REIS, R.B.; FARIA, B.N.; GONÇALVES, L.C.; COELHO, S.G.; SATURNINO, H.M. Silagens de girassol e de milho em dietas de vacas leiteiras: consumo e digestibilidade aparente. Arquivo Brasileiro de Medicina Veterinária e Zootecnia, v.58, n.6, p. 1192-1198, 2006.

MACEDO, V.P.; GARCIA, C.A.; SILVEIRA A.C.; MONTEIRO, A.L.G.; MACEDO, F.A.F. E SPERS, R.C. Composições tecidual e química do lombo de cordeiros alimentados com rações contendo semente de girassol em comedouros privativos. Revista Brasileira de Zootecnia, v.37, n.10, p.1860-1868, 2008.

MARANHÃO, C.M.DE A.; SILVA, C.C.F.DA; BONOMO, P.; PIRES, A.J.V. Produção e composição químicobromatológica de duas cultivares de Braquiária adubadas com nitrogênio e sua relação com o índice SPAD. Acta Scientiarum. Animal Sciences, v.31, p.117-122, 2009.

McDONALD, P. The biochemistry of silage. Chichester: John Wiley, 1981. $128 \mathrm{p}$.

MUCK, R.E.; SHINNERS, K.J. Conserved forage (silage an hay): progress an priorities. In:

INTERNATIONAL GRASSLAND CONGRESS, 19., São Pedro, 2001. Proceedings... Piracicaba: FEALQ, 2001. p.753.

OLIVEIRA, L.B.; PIRES, A.J.V.; CARVALHO, G.G.P.; RIBEIRO, L.S.O.; ALMEIDA, V.V.; PEIXOTO, C.A.M. Perdas e valor nutritivo de silagens de milho, sorgo Sudão, sorgo forrageiro e girassol. Revista Brasileira de Zootecnia, v.39, n.1, p.61-67, 2010. 
PLAYNE, M.J.; McDONALD, P. The buffering constituents of herbage and of silage. Journal of the Science of Food and Agricultural, v.17, p.264-268, 1966.

POSSENTI, R.A.; FERRARI JUNIOR, E.; BUENO, M.S.;

BIANCHINI, D.; LEINZ, F.F.; RODRIGUES, C.F. Parâmetros bromatológicos e fermentativos das silagens de milho e girassol. Ciência Rural, v.35, n.5, p.1185-1189, 2005.

REZENDE, A.V.; EVANGELISTA, A.R.; BARCELOS, A.F.; SIQUEIRA,G.R.; SANTOS, R.V.; MAZO, M.S. Efeito da mistura da planta de girassol (Helianthus annuus L.) durante a ensilagem do capimelefante (Pennisetum purpureum Schum.) no valor nutritivo da silagem. Revista Brasileira de Zootecnia, v.31, n.5, p.1938-1943, 2002.

SILVA, D.J.; QUEIROZ, A.C. Análise de alimentos: métodos químicos e biológicos. 3. ed. Viçosa, MG: UFV, 2002. 235p.

SOUZA, B.P.S.; COELHO, S.G.; GONÇALVES, L.C.; VIEIRA, F.A.P.; BORGES, A.L.C.C.; RODRIGUEZ, N.M.; RODRIGUES, J.A.S.; BORGES, I.; SALIBA, E.S. Composição bromatológica da silagem de quatro genótipos de girassol, ensilados em cinco diferentes idades de corte.

Arquivo Brasileiro de Medicina Veterinária e Zootecnia, v.57, p.204211, 2005. Supl. 2.
TILLEY. J.M.A.; TERRY, R.A. A two stage technique for in vitro digestion of forages crops. Journal of the British Grassland Society, v.18, n.2, p.104111, 1963.

TOMICH, T.R.; GONÇALVES, L.C.; TOMICH, R.G.P.; RODRIGUES, J.A.S.; BORGES, I.; RODRIGUEZ, N.M. Características Químicas e Digestibilidade in vitro de Silagens de Girassol. Revista Brasileira de Zootecnia, v.33, n.6, p.1672-1682, 2004 Supl. 1.

TOMICH, T.R.; RODRIGUES, J.A.S.; GONÇALVES, L.C.; TOMICH, R.G.P.; CARVALHO, A.U. Potencial forrageiro de cultivares de girassol produzidos na safrinha para ensilagem. Arquivo Brasileiro de Medicina Veterinária e Zootecnia, v.55, n.6, p.756-762, 2003.

VAN SOEST, P.J. Nutritional ecology of the ruminant. 2.ed. Ithaca: Cornell, 1994. 476p.

Data de recebimento: 11/04/2015

Data de aprovação: 14/02/2017 